\title{
MYXEDEMA WITH COMPLETE A-V BLOCK AND ADAMS-STOKES DISEASE ABOLISHED WITH THYROID MEDICATION
}

\author{
BY \\ JONG K. LEE, and J. A. LEWIS \\ From the Heart Service, Westminster Hospital, Dept. of Veterans' Affairs, London, Ontario, Canada.
}

The clinical characteristics of cardiac involvement in myxœdema were first described by Zondek (1918). Dilatation of the heart coupled with slowing and decreased vigour of its action were noted, as well as decreased amplitude of the $\mathbf{P}$ and $\mathbf{T}$ waves of the electrocardiogram. Fahr (1925) confirmed these electrocardiographic signs and observed their return to normal on treatment with thyroid extract. The patients presented with advanced congestive heart failure, unaffected by digitalis, but relieved by thyroid extract (Zondek, 1918; Fahr, 1932).

Disorder in cardiac rhythm was first described in this disease in 1918 in a patient with complete heart block with acceleration of auricular rate with thyroid medication (Aub and Stern, 1918); the total block was persistent in spite of treatment with thyroid extract. Schantz and Dubbs (1951) reported a similar case, but reversion to sinus rhythm occurred with thyroid extract. Our report zoncerns a patient with complete heart block complicated by Adams-Stokes attacks with reversion to sinus rhythm following the administration of thyroid extract.

\section{Case Report}

The patient was a 72-year old white veteran, admitted to Westminster Hospital for treatment of severe zongestive heart failure, disabling angina and fainting spells. Increasing angina had been treated with nitroslycerine for four years prior to admission. He was found to be pale, with a dry scaly skin, a croaking voice and puffiness of the eyelids and face. No thyroid tissue was palpable. The heart was enlarged to the eft. The heart rate was 36 a minute with a totally irregular rhythm and muffled heart sounds. The blood reasure was 140/72. Fine and medium râles were present in the lower lobes of both lungs. The liver was palpably enlarged and ascites and peripheral œdema were present. The teleroentgenogram showed moderate diffuse cardiac enlargement. The electrocardiogram (Fig. 1) showed marked sinus bradycardia with an irregular idioventricular rhythm, more rapid than the atrial rate. Pertinent laboratory findings were as follows: basal metabolic rate, minus 22 per cent; blood cholesterol, $395 \mathrm{mg}$. per cent; protein bound iodine (serum) $1.0 \mathrm{mcgm}$. per cent; radioactive iodine uptake, 3 per cent in 24 hours, increasing to 4 per cent in 24 hours following T.S.H. stimulation; urinary 17 ketosteroids $6 \cdot 12 \mathrm{mgm}$. per cent; increasing to $35 \mathrm{mgm}$. per cent following A.C.T.H. stimulation.

The diagnosis of "myxœdema heart" was evident, but we had not observed complete heart block in this "ical context previously. Therapy was begun with mercaptomerin in 2 c.c. doses hypodermically. Four

3 after admission an Adams-Stokes seizure occurred. Isopropylnorepinephrine was administered at rout-hour intervals as sublingual tablets $(15 \mathrm{mgm}$.) without acceleration of ventricular rate. At the same time, treatment with thyroid extract in a daily dose of one-eighth grain was commenced. Angina increased in frequency and attacks of acute pulmonary œdema appeared. In the intervals between attacks, the patient moported slight improvement in his feeling of bodily warmth and interest in life. Thus encouraged, the dose of thytoid extract was gradually increased, reaching two-fifths of a grain in the sixth hospital week. At this 


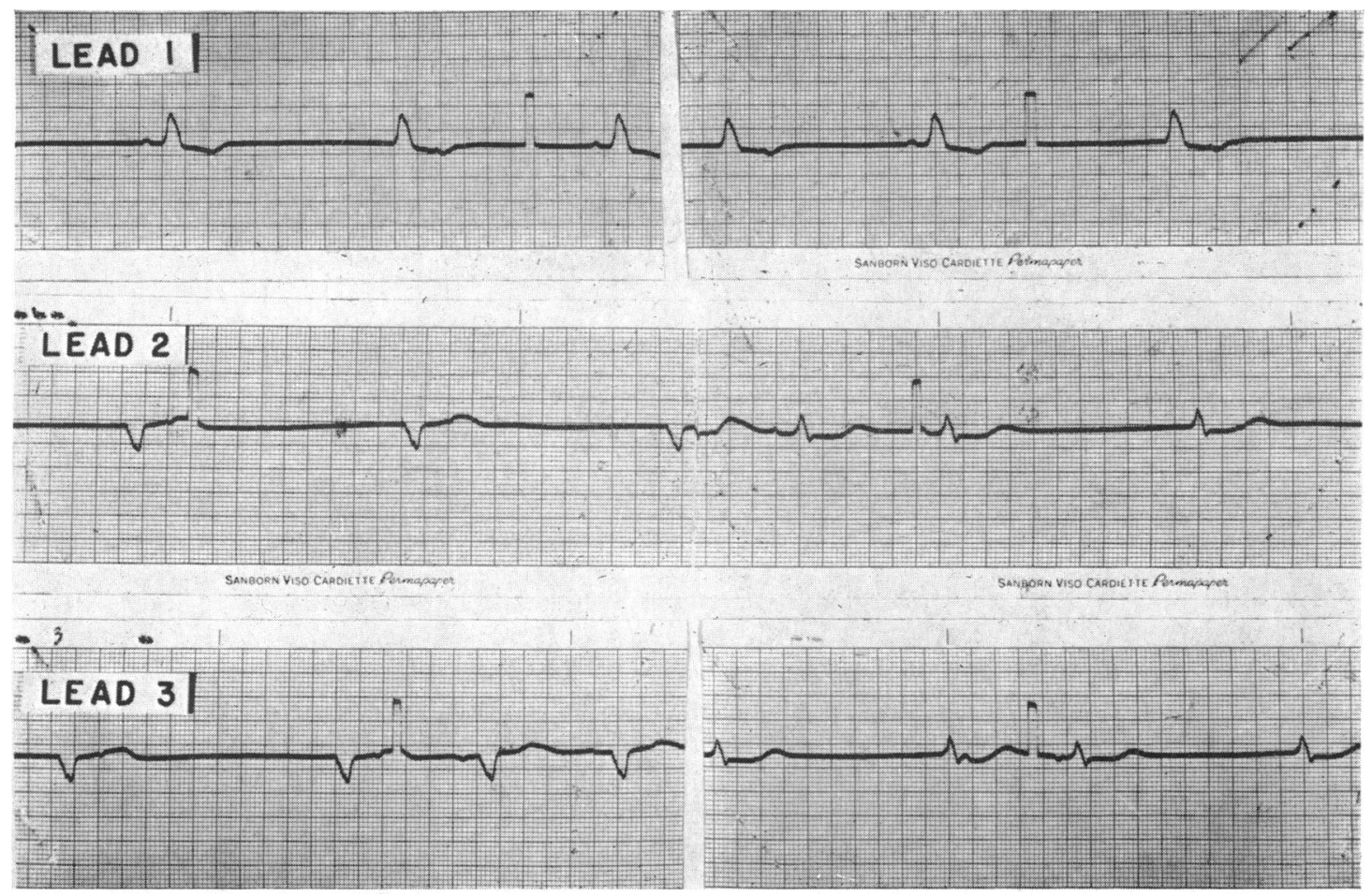

Fig. 1.-Electrocardiogram showing complete heart block with atrial bradycardia and irregular idioventricular beats.

time the electrocardiogram showed return to sinus rhythm (Fig. 2). The blood cholesterol had fallen to $240 \mathrm{mgm}$. per cent; the patient had become more alert, had thrown off some of his bed coverings and now spoke clearly.

During the ensuing two weeks the dose of thyroid extract was increased slowly. Serial electrocardiograms showed an unstable rhythm, alternating between sinus rhythm and sinus bradycardia with irregular idioventricular beats. When the dose of thyroid extract had reached one-half grain daily, the patient sustained a severe præcordial pain of several hours duration with a rise in the serum glutamic oxaloacetic transaminase to 168 units. However, no alteration appeared in serial electrocardiograms. Treatment with thyroid extract was continued and further increased without recurrence of prolonged pain.

After four and one-half months in hospital, thyroid extract was gradually replaced with triiodothyronine. One month after this transition was accomplished, all signs of congestive heart failure had disappeared and the patient was sitting out of bed most of the day and walking short distances. He was then discharged from hospital, taking triiodothyronine $25 \mathrm{mcgm}$. a day as his only medication. When seen in the Heart Clinic in this hospital one month later, he reported that he was feeling stronger; there was no evidence of congestive failure and the electrocardiogram showed persistence of sinus rhythm.

\section{Discussion}

The association of angina pectoris with myxœdema has been reported frequently (Zondek, 1918; Peel, 1943; Smyth, 1938). Thyroid extract increases the cardiac output and the myocardial oxygen consumption. Therefore, when myxœdema is complicated by angina, the initial doses of thyroid extract must be small and the rate of increment slow. It is possible, if not probable, that our patient, 


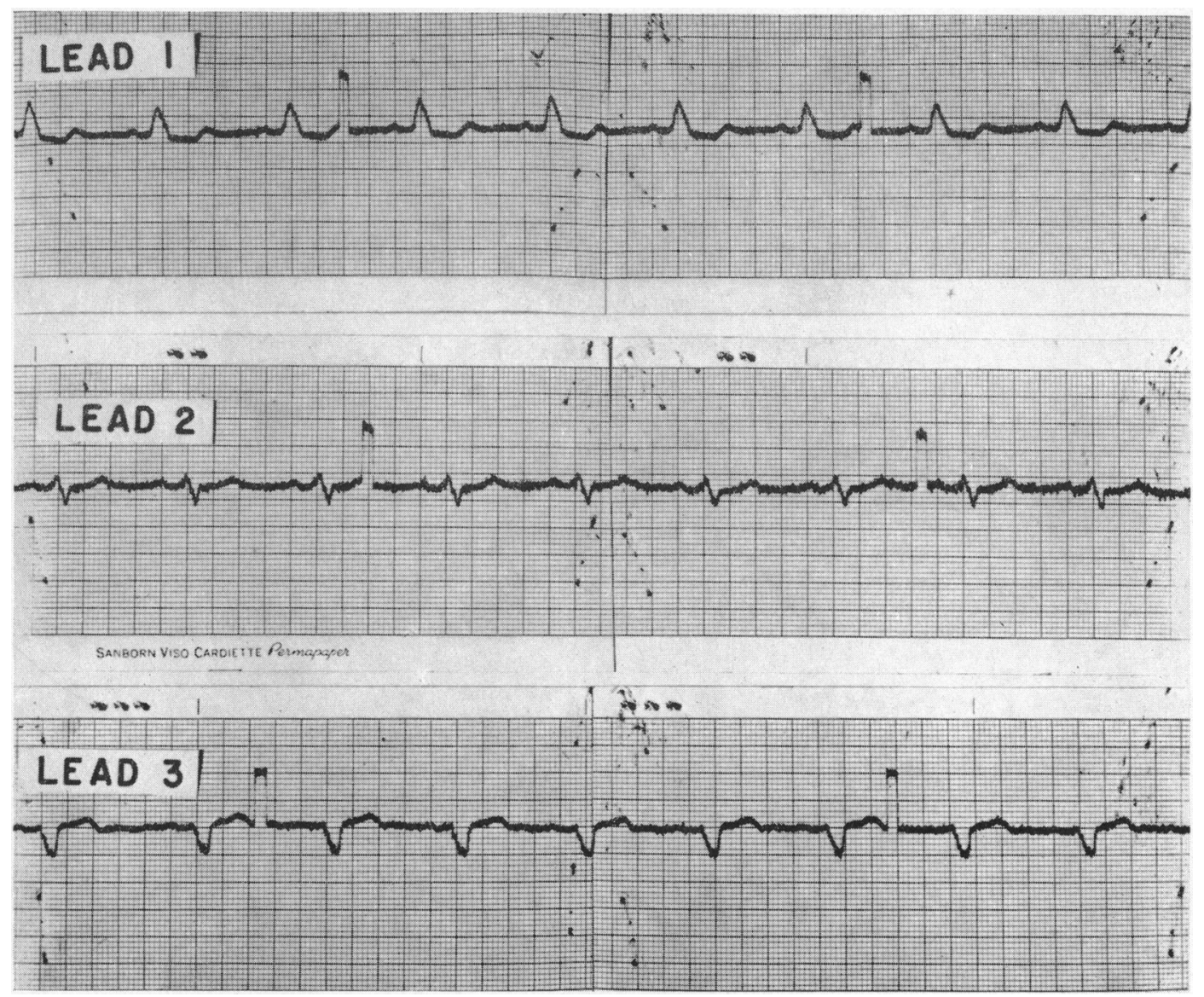

FIG. 2.-Electrocardiogram showing a return to sinus rhythm on thyroid hormone (see text).

sustained myocardial infarction during the eighth week of treatment, while receiving a half grain of thyroid extract daily. Diminution and disappearance of angina similar to that observed six weeks later, when on still larger doses of thyroid, has been reported (Beach, 1935; Beaumont and Robertson 1939).

Abnormalities of cardiac rhythm associated with myxœdema have been reported. Paroxysmal atrial tachycardia and atrial fibrillation have been observed (Ohler and Abramson, 1934). Fahr reported the occurrence of intraventricular conduction disturbance, disappearing with the administration of thyroid extract. First degree heart block occasionally abolished by thyroid medication has been described (David, 1930; Ohler and Abramson, 1934). Second degree (Luten, 1930) and complete heart block (Schantz and Dubbs, 1951) have been recorded; the latter reverting to sinus rhythm with treatment of the myxœdema. Willius (1924) and Drake (1928) observed a therapeutic effect from thyroid hormone in Adams-Stokes disease in the euthyroid patient. The observations of Nathanson and Miller (1950 and 1952) suggest that thyroxin is not a stimulant to the rhythmic property of the heart in the euthyroid state.

The mechanism of conduction disturbance within the heart of the myxœdematous patient is obscure. From the reported case of Schantz and Dubbs (1951) and the present patient, it would seem that effective therapy with thyroid extract will reverse this arrhythmia. 


\section{Summary}

An instance of complete heart block with Adams-Stokes attacks in a patient with myxœdema is reported; the arrhythmia was abolished by treatment with thyroid hormone. Earlier reports relating. to this condition are reviewed briefly.

Gratitude is expressed to Dr. E. A. Fergusson, Hospital Superintendent, and to Dr. C. H. Lockwood for clinical advice and assistance in the management and investigation of the patient.

\section{References}

Aub, J. C., and Stern, N. S. (1918). Arch. intern. Med., 21, 130.

Beach, C. H. (1935). J. Amer. med. Ass., 105, 871.

Beaumont, G. E., and Robertson, J. J. (1939). Lancet, 1, 682.

David, J. D. (1930). Ann. intern. Med., 4, 733.

Drake, E. (1928). Amer. Heart J., 31, 560.

Fahr, G. (1925). J. Amer. med. Ass., 84, 345.

- (1932). Amer. Heart J., 8, 91.

Luten, D. (1930). J. Missouri med. A., 126, 73.

Nathanson, M. H., and Miller, H. (1950). Calif. Med., 72, 215.

- - (1952). Circulation, 6, 238.

Ohler, W. R., and Abramson, J. (1934). Arch. intern. Med., 53, 165.

Peel, A. A. F. (1943). Brit. Heart J., 5, 89.

Schantz, E. T., and Dubbs, A. W. (1951). Amer. Heart J., 41, 613.

Smyth, C. J. (1938). Amer. Heart J., 15, 652.

Willius, F. (1924). Canad. med. Ass. J., 14, 1072.

Zondek, H. (1918). Munchen Med. Wchnsch., 65, 1180. 